\title{
Ellentétek feloldása a bankrendszerek versenyképességének mérésében - az MNB bankrendszeri versenyképességi indexe*
}

\author{
Asztalos Péter - Horváth Gábor - Krakovský Štefan - Tóth Tamás
}

Egy nemzetgazdaság versenyképessége strukturálisan függ a pénzügyi közvetités hatékonyságától és minőségétöl, amely szoros kapcsolatban áll a bankrendszeri versenyképességgel. Nézöpontunk szerint a bankrendszeri versenyképesség a bankrendszernek a gazdasági növekedést hosszú távon támogató jellegén keresztül ragadható meg, ami a gyakorlatban a pénzügyi erőforrások hatékony allokációján keresztül valósul meg. Kutatásunk során az európai országok bankrendszereinek versenyképességét mérő indexet fejlesztettünk ki-ismereteink szerint elsőként, amely a versenyképességet két, esetenként akár ellentétes perspektivából, a felhasználói és befektetői oldalról egyaránt modellezi, és a kapott eredményeket szintetizálja. Az elemzés rámutat a hazai bankrendszer jelentös lemaradására a lakossági hitelek árazása, a digitalizáció és a hatékony banki müködés területén, illetve bemutatja a versenyképes bankrendszerrel rendelkező nemzetgazdaságok versenyelöny-forrásait.

Journal of Economic Literature (JEL) kódok: E51, O40, E44

Kulcsszavak: finanszírozás, tőkevonzó képesség, stabilitás, növekedés, versenyképesség

\section{Bevezetés}

Elemzésünk célja az európai országok bankrendszereinek szisztematikus összehasonlítása versenyképességi aspektusból. Egy nemzetgazdaság versenyképessége számtalan intézményi, földrajzi, anyagi és humán tényező függvénye, amelyek között számottevő szerepet játszik a pénzügyi intézményrendszer, és azon belül a pénzügyi közvetítők. A pénzügyi rendszer és a gazdaság fejlődése közötti kapcsolat központi szerepet foglal el Gerschenkron (1962) nagy hatású könyvében is, amely bemutatja,

* Jelen cikk a szerző nézeteit tartalmazza, és nem feltétlenül tükrözi a Magyar Nemzeti Bank hivatalos álláspontját.

Asztalos Péter a Magyar Nemzeti Bank elemzője. E-mail: asztalosp@mnb.hu.

Horváth Gábor a Magyar Nemzeti Bank vezető közgazdasági szakértője. E-mail: horvathga@mnb.hu.

Krakovský Štefan a Magyar Nemzeti Bank elemzője.E-mail: krakovskys@mnb.hu.

Tóth Tamás a Magyar Nemzeti Bank elemzője. E-mail: tothtamas1@mnb.hu.

A magyar nyelvű kézirat első változata 2017. június 22-én érkezett szerkesztőségünkbe.

DOI: http://doi.org/10.25201/HSZ.16.3.531 
hogy az egyes korszakokban milyen modellek szerint történt az iparosítás és ezzel a gazdasági felzárkózás finanszírozása. A közkeletú értelmezés szerint a pénzügyi közvetítés a pénzügyi erőforrások összegyűjtése és hatékony allokálása, aminek nem megfelelő mivoltából adódó hátrányokra már Hicks (1935) is rámutatott. Amennyiben ez megfelelően zajlik, akkor minden érintett „jól jár": emelkednek a megtakarítások, bővülnek a beruházások és a bankrendszer önmaga is nyereséges, ami szükséges tevékenysége hosszú távú folytatásához. Ilyen módon a pénzügyi közvetítő rendszer nagymértékben hozzájárul a fenntartható, dinamikus gazdasági növekedéshez ${ }^{1}$, azaz a versenyképességhez. A fenti, nagymértékben leegyszerüsített gondolatmenet részletes elemzéséhez két kérdés vizsgálandó:

a) Mivel jellemezhető és hogyan mérhető egy ország bankrendszerének versenyképessége önmagában?

b) Milyen csatornákon keresztül járul hozzá a bankrendszer a teljes nemzetgazdaság versenyképességéhez?

Elemzésünkben az első kérdést helyezzük a középpontba. A bankrendszeri versenyképesség megfelelő értelmezése és egy adott bankrendszer strukturális jellemzőinek részletes vizsgálata reményeink szerint közelebb visz nemcsak a pénzügyi rendszerek, hanem teljes gazdaságok jobb megértéséhez. Ezen felül egy átlátható nemzetközi összehasonlítás segítheti hazánk bankrendszerével kapcsolatos fejlődési lehetőségeinek azonosítását, amely törekvés összhangban áll a Magyar Nemzeti Bank (MNB) törvényi mandátumaival is.

A vizsgálat során az első dilemmát a bankrendszeri versenyképesség értelmezése és mérhetősége adja. A bankrendszer versenyképessége nem jól definiált vagy magától értetődő fogalom. Elemzésünkben abból a megközelítésből indultunk ki, hogy a pénzügyi közvetítés célja - és így a jól működő bankrendszer ismérve - a pénzügyi erőforrások hatékony, a növekedést hosszú távon támogató allokációja. A méréshez felhasznált mutatók körét ebből az értelmezésből vezettük le. Ez összecseng az MNB által korábban publikált tanulmánnyal a jól működő bankrendszer 10 ismérvéről (MNB 2014), amelyben a kiemelt tényezők között szerepel az egészséges hitelezés, a bankrendszer önfinanszírozásának fontossága, a növekedés támogatása, illetve a hatékonyságnövelésben és innovációban rejlő potenciál. A bankrendszer versenyképességének időbeli és nemzetközi összehasonlításához ezen dimenziók számszerű felmérése és aggregálása szükséges.

A mérhetőség tekintetében - elfogadva a bankrendszeri versenyképesség fenti koncepcióját - a mutatók körének és optimális mértékének megválasztása jelenti a kihívást. Számos szereplő perspektívájából szemlélhető a hatékony pénzügyi allo-

${ }^{1}$ Bővebben a Versenyképesség és növekedés 4. fejezete foglalkozik a kérdéssel: A pénzügyi közvetítés szerepe a növekedésben (Banai et al. 2016). 
kációhoz szükséges feltételrendszer. Az állam és a szabályozó hatóság, a fogyasztók és a bankok oldaláról egyaránt vizsgálhatjuk a pénzügyi közvetítés adottságait, akár egymásnak ellenfeszülő szempontokat is figyelembe véve. A pénzügyi rendszert piaci keretekben elgondolva számunkra a felhasználói (háztartások és vállalatok), valamint az infrastruktúrát szolgáltató oldal elemzésén keresztül vált legkönnyebben értelmezhetővé és mérhetővé a hatékony és fenntartható forrásallokáció, mint a bankrendszeri versenyképesség definíciója. Ez a megközelítés lehetőséget ad környezeti és keresleti tényezők figyelembevételére, ami egy-egy nemzetgazdaság strukturális adottságainak, illetve az adott bankrendszer versenyképességének szempontjából is meghatározó. Ezeknek a tényezőknek az alakulására a bankok kevésbé, inkább az állam és a szabályozó hatóságok képesek hatni középtávon.

A pénzügyi közvetítés felhasználóinak és strukturális oldalának ellentétes szempontjait szem előtt tartva a tanulmányban e két szemszögből így külön-külön közelítjük meg a bankrendszer versenyképességét:

- Vállalati és háztartási finanszírozás: A háztartások és a vállalatok szemszögéből nézve annak van kulcsszerepe, hogy megfelelően betölti-e a bankrendszer a pénzügyi közvetítés funkcióját, támogatja-e az ügyfelek pénzügyi bevonódását. A kereslet oldali versenyképesség ezért megítélésünk szerint a hozzáférhetőség, a minőség és az árazás dimenziókban ragadható meg leginkább, vagyis ha a pénzügyi termékek széles körben, megfizethető áron és magas minőségben jelennek meg. A felhasználó oldal elemzése így képet adhat arról, hogy a racionális ügyfelek egy hipotetikus választás esetén mely országok bankrendszereit részesítenék előnyben.

- Tőkevonzó képesség: Másfelől a banktulajdonosok és befektetők részéről öt meghatározó szempontot választottunk, amelyek döntőek lehetnek, amikor a tevékenységük folytatásáról vagy bővítéséről döntenek. Ezek a stabilitás, a jövedelmezőség, a múködési és adókörnyezet, a pénzügyi mélyülés lehetőségei, valamint a technológia és hatékonyság.

A vállalati és finanszírozási index összeállítása során olyan mutatók is szerepet kapnak, amelyek nem kizárólag a keresleti oldal által meghatározottak, hanem értékük a kereslet és a kínálat egyensúlyaként alakul ki. Példaként említhetőek az árazási mutatók, amelyek egyrészről a felhasználók kereslet oldali megítélését mutatják, másrészt azonban a pénzügyi rendszer diverzifikáltságát, illetve a verseny intenzitását tükrözik.

Tovább nehezíti a feladatot, hogy a kiemelt szereplőknek - különösen a bankrendszer felhasználóinak és tulajdonosainak - más-más, esetenként ellentétes szempontjai vannak a versenyképességet tekintve. Az egyik leginkább kézenfekvő az árazásban fennálló érdekellentét: a hitelfelvevő minél alacsonyabb felárral és kamattal keres 
hitelt, míg a bankrendszer és annak tulajdonosi nézőpontjából a minél magasabb marzsok, ezáltal a magas jövedelmezőség és tőkeakkumulációs képesség az elsődleges. Hasonlóképpen, a felhasználók minél könnyebben elérhető szolgáltatásokat igényelnek, de egy túlságosan széles fiókhálózat a fenntartási költségeken keresztül ronthatja is a bankrendszer hatékonyságát. Érdemes azt is figyelembe venni, hogy a befektetők sokszor a hozam növelését részesíthetik előnyben az optimális allokáció megvalósításával szemben. Végül, a felhasználók számára a minél érettebb, mélyebb és versenyző banki piac a kedvező, de a befektetők számára ez kevesebb növekedési lehetőséget tartogat, így kevésbé lehet vonzó.

A felhasználói és befektetői oldali versenyképesség közötti statikus ellentét azonban az idővel oldódik, és ezek hosszabb távon egymást erősítő tényezőkké válhatnak. Ha egy adott országban alacsony a tőkevonzó képesség, és így nem tud kiépülni megfelelő banki infrastruktúra, akkor alacsonyabb lesz a pénzügyi rendszerben való részvételi hajlandóság, és ezzel csökken a pénzügyi közvetítés hatékonysága. A drágább, alacsonyabb minőségű kiszolgálás és gyengülő elérhetőség egyre kevésbé hatékony múködéshez vezet, ami pedig csökkenő tőkearányos megtérülést és még alacsonyabb tőkevonzó képességet eredményez. Ebből az ördögi körből kitörni némileg magasabb árazáson keresztül lehetséges, amíg a kiépülő infrastruktúra tőkeköltsége megtérül. Hosszú távon természetesen mindkét nézőpontnak (felhasználói és befektetői) meg kell felelni ahhoz, hogy egy bankrendszer fenntarthatóan és a növekedést hatékonyan támogatva működjön. A két index eredményeit ez okból célszerü együttesen is figyelembe venni, hogy látható legyen, mely országokban sikerült a leginkább összeegyeztetni e két, sok esetben akár ellentétes szempontot a bankrendszer múködésében.

A versenyképesség alapvetően hosszú távon értelmezhető és strukturális tényezőkön alapul (Porter 1998), ám a ciklikus mutatók is magas információtartalommal rendelkezhetnek (Nafzinger 2006). A bankrendszerben tapasztalt prociklikus múködés a hitelezési aktivitáson, valamint a kockázatalapú versengésen keresztül valósul meg, és számottevően hozzájárulhat a gazdasági növekedés ingadozásához (Claessens 2009). Azért lehet ez káros, mert válságok előtt felerősíti a buborékok felfúvódását, és így mélyíti, valamint el is nyújthatja az utána következő recessziót. A súlyosabb válságok és a lassabb kilábalás a gazdasági növekedés hosszú távú átlagát is befolyásolhatja, tehát hat a versenyképességre, ha azt a hosszú távú fejlettségi potenciálként értelmezzük (Hatzichronoglou 1996). Mivel a bankrendszeri versenyképesség definíciónk szerint a hatékony pénzügyi allokációt jelenti, ez egy prociklikus bankrendszert nem jellemezhet - a pénzügyi cikluson átívelő értékelés bemutatná a túlfütött hitelezés és megnövekedett kockázati költségek után lecsökkenő kockázati étvágy növekedési áldozatait. Így, ha a fentebb megállapított két aspektusban versenyképesnek bizonyul egy bankrendszer, az egyben a prociklikus 
múködés valószínúségét is lecsökkenti, vagyis stabilan és prudensen, egyetlen szóval összefoglalva hatékonyan látja el a források elosztását hosszabb távon is.

A következő fejezetben a bankrendszeri versenyképességet mérő mutatószám-rendszer összeállítása során felmerült módszertani kérdéseket tárgyaljuk. Ezt követően bemutatjuk, hogy a két különböző oldalról végzett felmérés során milyen mutatókat használtunk, miért ezekre esett a választás, és milyen eredményeket adnak. Az ötödik fejezet a két megközelítés együttes eredményét tartalmazza, végül pedig összegezzük az eredményeket és megjelölünk néhány lehetséges további kutatási irányt.

\section{Módszertan}

A vizsgálat tárgya, a bankrendszeri versenyképességi rangsor felállítása területileg az Európai Unió tagállamaira terjed ki, mivel az adatok konzisztensen és összehasonlíthatóan az európai uniós országokra állnak rendelkezésre. Törekedtünk arra, hogy a lefedni kívánt területeket minél inkább objektív adatok alapján hasonlítsuk össze. Az adatforrások közül a legtöbb mutató a Világbank Global Findex Database-éból és az Európai Központi Bank Survey on the access to finance of enterprises (SAFE) felméréséből kerül felhasználásra. Ezen felül megjelenik a források között az OECD, az Eurostat, a Standard and Poors, illetve valamennyi nagyobb általános versenyképességi rangsor (World Economic Forum Global Competitiveness Report, World Competitiveness Yearbook, Doing Business) is.

A bankrendszeri versenyképességet mérő adatok aggregálásához, az indexek elkészítéséhez - a nemzetközi gyakorlathoz hasonlóan - többszintű hierarchiát határoztunk meg:

I. Alapmutató: a banki múködés vagy környezet egy-egy jellemzőjét leíró számszerü érték, amely már önmagában is lehet akár több tényezőt is figyelembe vevő mutató (pl. I.A.1. Bankfiókok száma 100 ezer lakosra).

II. Alpillér: tematikusan egy körbe tartozó alapmutatók egy olyan csoportja, amely lefedi a banki múködés vagy környezet egy-egy jól definiálható területét (pl. I.A. Banki infrastruktúra).

III. Főpillér: tematikusan egy körbe tartozó alpillérek egy olyan csoportja, amely lefedi a banki múködés egy átfogó területét. Csak a háztartási és vállalati finanszírozás területén alkalmaztuk (pl. I. Hozzáférés).

IV. Index: a bankrendszeri versenyképesség mértékét egy meghatározott szempontból egy számba sűrítő összetett mutató (pl. Vállalati és háztartási finanszírozási index). 


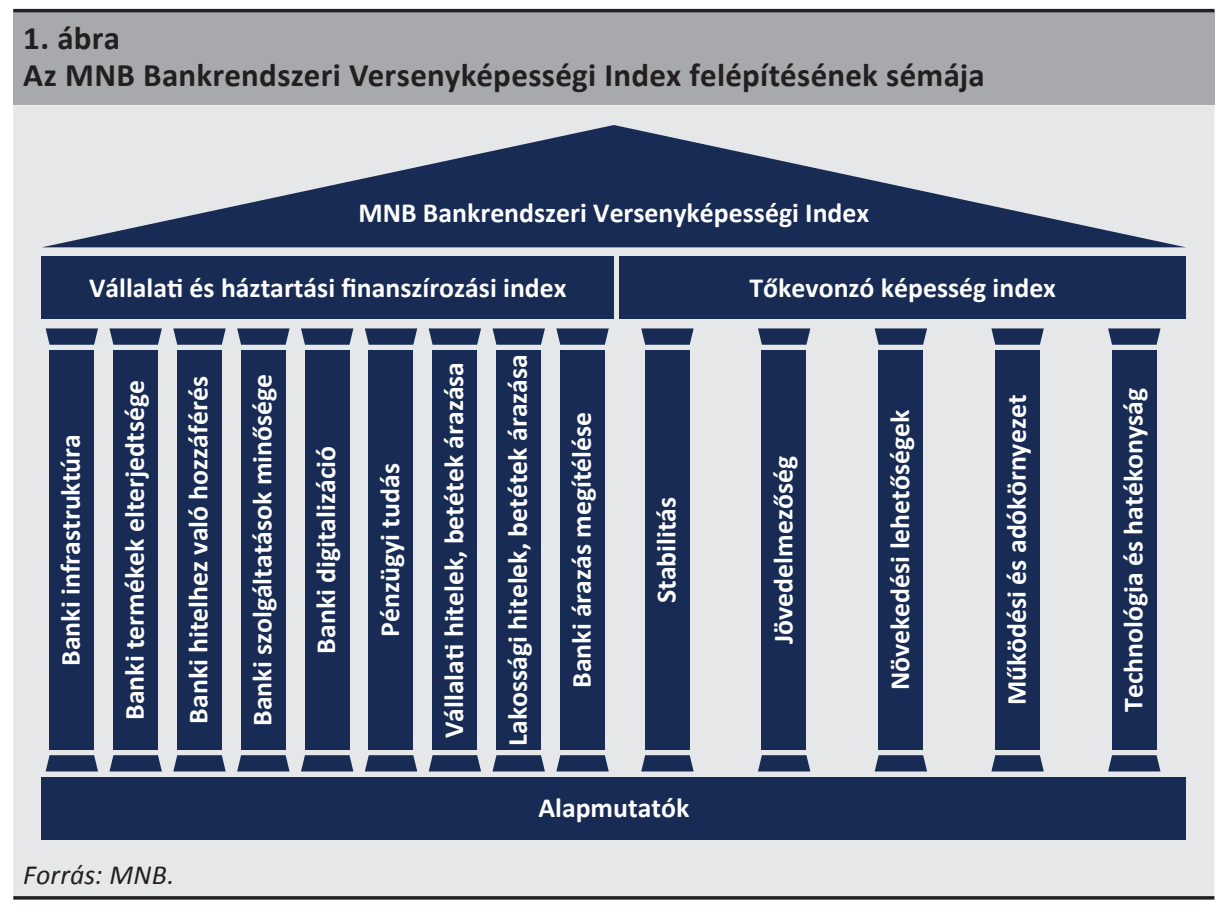

A bankrendszer versenyképességét jellemző indexek megalkotásakor módszertani szempontból három alapvető kérdést szükséges tisztázni:

1) Mit tekintünk optimális értéknek az egyes alapmutatók esetében?

2) Hogyan történik az egyes alapmutatók esetében a pontszámítás?

\section{3) Az alapmutatók milyen súlyozással állnak össze egy indexszé?}

Az indexek létrehozásához szükséges meghatározni, hogy az egyes alapmutatók esetében a skála melyik részét tekintjük optimális értéknek (maximális, minimális vagy akár átlagos értékét). Ez a legtöbb esetben magától értetődő, helyenként azonban nehézségbe ütközik, ami egyrészt abból származhat, hogy nem dönthető el, hogy a magasabb vagy az alacsonyabb szint a kedvezőbb, másrészt abból, ha nem egy szélső érték látszik a leginkább optimálisnak (nem lineáris a skála). Előbbi dilemma például az árazás és az infrastruktúra esetében merülhet fel. Azonban e problémákat megoldotta, hogy a felhasználók és a bankrendszer befektetői oldala felől két külön indexet vizsgáltunk, és az egyértelműnek látszott, hogy a két eltérő nézőpontból melyik a kedvezőbb érték. A második dilemma abból fakadt, hogy néhány általunk számított mutató esetében megkérdőjelezhető volt a skála lineáris jellege. Mivel optimális sávok meghatározását célérték hiányában nem tartottuk objektív módon kivitelezhetőnek, az optimumot ilyenkor a minta átlagával határoztuk meg, az országokat pedig az átlagtól számított eltérésük alapján pontoztuk. 
Az áttekinthető értékelés érdekében azt a célt tűztük ki, hogy valamennyi alapmutató tekintetében 0-100 közötti skálán pontozzuk az eredményeket, figyelembe véve nemcsak a relatív értékeket, hanem a minta szórását is. Az alapmutatók nyers értékeinek standardizálásához és az ebből fakadó pontszámításhoz áttekintettük a legnagyobb nemzetközi versenyképességi indexek által alkalmazott módszereket:

a) World Bank (WB) - Doing Business (DB): ez a rangsor a distance to frontier módszertant alkalmazza, amelynek során a legmagasabb ország 100 pontot kap, a legalacsonyabb 0-t, a többieket pedig ezek között értékelik az alábbi képlettel (World Bank 2017):

([legrosszabb érték] - [az adott ország értéke]) / ([legrosszabb érték] - [legjobb érték]) *100

b) World Economic Forum (WEF) - Global Competitiveness Report (GCR): a Doing Business rangsorhoz hasonlóan szintén a distance to frontier elven múködő módszertant alkalmazza, de 1-7 közötti értékekhez jut (Schwab 2017):

6* (([az adottország értéke]-[legrosszabb érték])/([legjobb érték]-[legrosszabb érték])) +1

c) IMD - World Competitiveness Yearbook (WCY): elsősorban a rangsorolást tartja szem előtt, és az alapmutatókat standardizálja ugyan, de nem képez belőle pontszámokat (IMD 2017).

A fenti képletek egyike sem felelt meg teljes mértékben az előzetes elvárásainknak, elsősorban azért, mert megítélésünk szerint nem tükrözték megfelelő mértékben az adatok szórását. A distance to frontier elven alapuló módszertan (WB, WEF) felnagyítja az nyers adatokban meglévő különbséget azáltal, hogy minden esetben a teljes skálára (0-100 pont) vetíti az eredményeket, függetlenül attól, hogy milyen az adott minta szórása. Az IMD által használt módszertan pedig elsősorban rangsorolásra alkalmas, ugyanakkor nem törekszik arra, hogy ehhez olyan összehasonlítható pontozást alkalmazzon, amilyet mi célul túztünk ki.

Az adatok szórásának figyelembevétele érdekében az alábbi képletet vezettük be és alkalmaztuk az alapmutatók pontszámmá konvertálásához:

$\operatorname{MAX}(0 ; 100-\{([$ legjobb érték] - [az adott ország értéke $]) /[$ szórás $]\}$ * $[P])$,

ahol a $[P]$ paraméter értéke annak súlyát mutatja meg, hogy mennyire „büntetjük” a legjobb értéktől való eltérés mértékét.

Ennek megfelelően a módszertanunk figyelembe veszi az adott minta szórását úgy, hogy a legmagasabb értéktől mért távolság arányában von le pontokat. A pontszámítási skála 0 és 100 pont között értelmezendő, ahol a rangsorban legjobb teljesítményt mutató ország mindig a maximális 100 pontot kapja, de nem minden mutató 
esetében alakul ki 0 pont, hanem csak akkor, ha a megfigyelési egységek több szórásnyi távolságra vannak a legjobb értéktől. További előnye a módszertannak, hogy a „büntetés” mértéke paraméterezhető a szórás függvényében. Számításaink során a $[P]$ = 25 értékkel kalkuláltunk, ami azt jelenti, hogy a legjobb értéktől 4 (és az ennél több) szórásnyi távolságban található eredmények érnek 0 pontot. Mint korábban említettük, néhány mutató esetében nem volt lehetséges lineáris mérce meghatározása. Ilyen esetekben az átlagtól, mint optimumtól számított távolság adta meg a szórásnyi távolságot, miközben $[P]=12,5$. Ezzel a megközelítéssel sikerült a legtöbb országot egyenletesen a 0-100 közötti skálára normálni.

Az alapmutatók és a pillérek súlyozása tekintetében a nemzetközi módszertanok egységesek és számunkra is megfelelőek (World Bank 2017; Schwab 2017; IMD 2017). Valamennyi vizsgált rangsor számtani átlag alkalmazásával készíti el a végső indexét, aminek során azonos súllyal veszi számításba az egyes alapmutatókat és pilléreket. E módszertan előnye, hogy egyszerűen áttekinthető és reprodukálható, illetve hogy megfelelő módon kezeli az esetleges adathiányokból adódó problémákat is. Az index végső súlyozására több különböző módszer is lehetséges annak függvényében, hogy mit tekintünk a számítás alapjának (az alapmutatókat, az alpilléreket, vagy a főpilléreket). A számítások során az alpilléreket vettük egyenlő súllyal számításba, mivel ezek már tematikusan rendszerezett alapmutatókból tevődnek össze, kezelik az adathiányok okozta problémákat, ugyanakkor számosságuk nagyobb, mint a főpilléreké, amelyek elemzését megnehezíti az általuk lefedett területek széleskörűsége. Robusztussági szempontból megvizsgáltuk az alapmutatókon és a főpilléreken alapuló súlyozási módszertanokat is, ám az így kapott eredmények szintén nem térnek el számottevően az általunk választott módszertan eredményeitől.

\section{Vállalati és háztartási finanszírozási index (VHFI)}

Abból indultunk ki, hogy felhasználói oldalról közelítve azt a bankrendszert tekintjük versenyképesnek, ahol a szolgáltatások széles körben és magas színvonalon elérhetőek, továbbá ezek árazása megfelelő, kigazdálkodható a lakossági és vállalati szereplők számára egyaránt, tehát a finanszírozás költsége nem lehetetleníti el a beruházásokat. Ennek alapján a felhasználói oldal mérése során három különböző dimenziót (hozzáférés, minőség, ár) azonosítottunk, amelyek egy-egy főpillért képeznek. Ezeket tovább bontottuk 3-3 homogénebb területet lefedő alpillérre, figyelembe véve vállalati és lakossági szempontú mutatókat is (lásd 1. táblázat). Az árazás alpillérben számos olyan mutató is található, amelyek értéke nem kizárólag a kereslet oldali tényezők által meghatározott, hanem a kereslet és kínálat egyensúlya mentén alakul ki. Mindezekkel együtt a vállalati és háztartási finanszírozási indexben a keresleti oldal kerül előtérbe, így a banki termékek árazásának elemzése során is a felhasználók megítélésére fókuszálunk. 


\begin{tabular}{|c|c|c|c|c|c|c|}
\hline \multicolumn{7}{|c|}{ MNB Vállalati és Háztartási Finanszírozási Index felépítése } \\
\hline \multicolumn{7}{|c|}{ Főpillérek } \\
\hline & I. & Hozzáférés & II. & Minőség & III. & Árazás \\
\hline \multirow[t]{3}{*}{ Alpillérek } & I.A. & Banki infrastruktúra & II.A. & $\begin{array}{l}\text { Banki szolgáltatások } \\
\text { minősége }\end{array}$ & III.A. & $\begin{array}{l}\text { Vállalati hitelek és } \\
\text { betétek árazása }\end{array}$ \\
\hline & I.B. & $\begin{array}{l}\text { Banki termékek } \\
\text { elterjedtsége }\end{array}$ & II.B. & Banki digitalizáció & III.B. & $\begin{array}{l}\text { Lakossági hitelek és } \\
\text { betétek árazása }\end{array}$ \\
\hline & I.C. & $\begin{array}{l}\text { Banki hitelhez való } \\
\text { hozzáférés }\end{array}$ & II.C. & Pénzügyi tudás & III.C. & $\begin{array}{l}\text { Banki árazás } \\
\text { megítélése }\end{array}$ \\
\hline
\end{tabular}

A hozzáférés főpillér a banki szolgáltatások elérhetőségét kívánja reprezentálni, amelyben az infrastruktúra, a termékek elterjedtsége, illetve a hitelezési aktivitás egyaránt szerepet kap. A banki infrastruktúra területe a pénzügyi rendszer fizikai és digitális elérhetőségét, kiépültségét jellemzi, amelyet a bankfiókok és az ATM-ek elterjedtségével, továbbá a hitelinformációs rendszer kiterjedtségével mérünk. Ez utóbbi a hitelek elbírálása során nyújt komoly segítséget a bankoknak, amely ügyfél oldalról nagyban meghatározza a tényleges hitelhez jutást. Míg banki oldalról ezek jelentősen növelik a költségeket, addig felhasználói oldalon még mindig alapvető fontosságú felületei a banki szolgáltatások igénybevételének. A fizikai infrastruktúra jelentősége mindazonáltal csökken a digitalizáció terjedésével, így vitatható, hogy elterjedtségük mennyire jó fokmérője a versenyképességnek. Az optimális fiókhálózat mértéke túlmutat elemzésünk keretein, ezért részben az egyszerüsítés érdekében úgy tekintettük, hogy a nagyobb fiókhálózat inkább előnyös felhasználói oldalról. Az alapmutatók kiválasztásakor elvetettük a kereskedelmi bankok számát, mivel nem tudtuk egyértelműen megállapítani, hogy a bankok számának mi az optimális értéke.

A banki termékek elterjedtsége értelemszerűen szerepet játszik a bankrendszer versenyképességében, megmutatva, hogy a potenciális felhasználók mekkora köre vált ügyféllé, milyen sikeres a pénzügyi inklúzió. Ebben a pillérben különösen domináns a keresleti tényező, de az elérhetőség is meghúzódik a háttérben. Ennek számszerūsítésére a bankszámlák és bankkártyák elterjedtségét és felhasználásuk jellemzőit (bankkártyás fizetés gyakorisága, jövedelem bankszámlára utalása) használtuk, kizárólag a lakossági szegmensre vonatkoztatva. E mutatók köre bővíthető, de vizsgálataink szerint több változó bevonása redundáns, mivel igen jelentős közöttük az együttmozgás. Megfontoltuk még a betétszámlák száma és a hitellel rendelkező háztartások aránya mutatókat is, de ezek esetében nem állt elég országra rendelkezésre adat.

A banki hitelhez való hozzáférés lényegében szintén a banki szolgáltatások elterjedtségét jelzi, de jelentőségénél fogva külön alpillérben kezeltük, felölelve benne a vállalati és a háztartási szektort egyaránt. A hitelek árazásán felül az alpillér a hitelfelvevők arányát, a hitelfelvétel bonyolultsági fokát, valamint a sikeres ké- 
relmek arányát is méri. A hitelfelvevők aránya egyszerúen a pénzügyi mélységet jelzi, amelyet jól kiegészít a többi mutató, ami bizonyos értelemben a bankok és a magánszektor összhangjára utal. A sikeres hitelkérelmek magasabb szintje utal egyfelől az igénylők magasabb pénzügyi tudatosságára, másfelől a kereslet és kínálat ciklikus összhangjára. A hitelfelvétel bonyolultsági foka szubjektív mutató, de ezt helyénvalónak is találtuk, mivel e tekintetben az ügyfél egyedi érzékelése számít, ami országonként, illetve a pénzügyi ismeretek mértékének függvényében eltérő lehet. Továbbá megjelenik a hitelkeretek mértékének emelkedését érző vállalkozások aránya is az alapmutatók között. Az alapmutatók kiválasztása során a nem megfelelő földrajzi lefedettség miatt elvetettük a hitelekkel rendelkező háztartások arányára vonatkozó EKB-mutatót.

A minőség főpillér a bankszektor szolgáltatási színvonalát, a banki digitalizáció fokát, valamint a lakosság és a gazdasági szereplők pénzügyi tudását foglalja össze. A lefedett témákból következően ez a nehezebben számszerűsíthető területek közé tartozik. Az objektiven legkevésbé mérhető alpillér a banki szolgáltatások minősége, amely 3 mutatóval a vállalati szektor banki szolgáltatásokkal kapcsolatos elégedettségét, illetve a fogyasztóvédelem jogi lehetőségeit méri. A „pénzügyi szolgáltatások igazodása a piaci igényekhez" mutató a WEF adatbázisából átemelve a vállalatvezetők általános benyomását érzékelteti arról, hogy a pénzpiac szolgáltatásai mennyiben találkoznak a vállalatok egyéni igényeivel, tehát a kereslet és kínálat egyensúlyának jelenlétére utal. A „bankokhoz bizalommal fordulók aránya” mutató forrása az EKB vállalati felmérése, tartalma pedig a vállalatvezetők pénzügyi szektorral szembeni általános bizalmi szintjeként jellemezhető. Mindkét mutató valamennyi uniós országban méri a fogyasztók elégedettségét, alapjuk a banki szolgáltatások minőségének - ügyfelek szerinti - szubjektív megítélése. Ezt egészíti ki az alpillérben szintén szereplő jogi lehetőségek mutatója (forrása a Világbank Doing Business felmérése), amely egy olyan 12 eldöntendő kérdésre épülő objektív alapmutató, amely felhasználói szempontból tényszerűen mutatja be a jogi védelem elérhető eszközeit a vizsgált országokban. A jogi védelem ez esetben jórészt a vállalatok pénzügyi szektorral szembeni védelmét jelenti (pl. a pénzügyi jogi keretrendszer meglétét vagy a szerződések jogi fórumokon való érvényesíthetőségét), leegyszerüsítve a vállalatok bankokkal szembeni kitettségét méri. A banki szolgáltatások minőségéről elvileg elképzelhető lenne egy szisztematikus, standardizált nemzetközi összehasonlítás, azonban szubjektív jellege ellenére a felmérést célnak megfelelőnek tartjuk. A bankrendszerrel szembeni elvárások országok közötti különbözősége torzíthatja a nemzetközi összehasonlítást, de az teljesen egybeesik a nézőpontunkkal, hogy e tekintetben közvetlenül a felhasználók kerültek megkérdezésre.

A banki digitalizáció vizsgálata során kitérünk az internetet bankolási célból használók, az interneten keresztül és a mobiltelefonnal vásárlók, illetve a digitálisan fizetést végzők és kapók arányára egyaránt. A digitalizáció témaköre egyfelől azért került 
a minőség főpillérbe, mivel úgy gondoljuk, hogy a digitális termékek használata az Európai Unióban alapvetően hozzáférhető, így a tényleges használók száma sokkal inkább tükrözi a nyújtott szolgáltatás színvonalát, illetve a bankok ilyen irányú nyitottságát, mintsem a hozzáférés lehetőségét. Másfelől a banki digitalizációt jelenleg a fizikai infrastruktúra kiegészítéseként értelmeztük, de a jövőben - a kereslet erősödésével - mindinkább annak helyettesítőjévé válhat. Amennyiben a jövőben ki fogja váltani a hagyományos banki infrastruktúrát, akkor indokolt lesz a „hozzáférés" pillérbe átsorolni.

A pénzügyi tudás részben a felhasználók ismereteit méri, mert megítélésünk szerint a bankrendszer versenyképességére visszahat, hogy az ügyfelek mennyire tájékozottak pénzügyeiket illetően. Az alpillér másik két mutatója viszont a gazdasági felsőoktatás színvonalát méri, amellyel már nemcsak az ügyfelek, de a bankrendszer humán erőforrásának képzettségét is le kívántuk fedni. A valamennyi vizsgált tényezővel összefüggő pénzügyi tudás alpillér azért került a minőség főpillérbe besorolásra, mert úgy gondoljuk, hogy ennek a külső környezeti tényezőnek fontos szerepe van abban, hogy a keresleti oldal miként reagál a pénzügyi termékekben bekövetkező újításokra. Emellett a bankoknak mint a lakossággal legszorosabb kapcsolatban álló pénzügyi intézményeknek, is érdekükben áll az ügyfelek pénzügyi ismereteinek bővítése, hiszen pénzügyileg tájékozottabb, illetve a saját tudásában jobban megbízó ügyfelek számára több, akár összetettebb és nagyobb hasznot hozó termékeket tudnak értékesíteni. Amennyiben a bankok nem járulnak hozzá - főként a kínált termékeik átláthatóságával és az ügyfélszolgálati munkatársak közérthető, de alapos felkészültségével - az ügyfelek pénzügyi tudatosságának fejlesztéséhez, az jelentősen csökkentheti egyrészt a megtérülően kihelyezett pénzügyi eszközök arányát, másrészt pedig a piaci versenyt a szektorban. Ha egy országban alacsony a pénzügyi múveltség mértéke, kiemelkedően fontos szerepet kap a bankok prudens és fogyasztóbarát viselkedése, illetve az ezt előiró szabályozás és a szabályok betartását vizsgáló fogyasztóvédelem is. Az MNB szempontjából éppen ezért kiemelten fontos e terület vizsgálata, folyamatos monitorizálása. Az országok gazdasági képzéseinek színvonalát az üzleti iskolák megítélésével és a gazdasági egyetemi képzésre járó diákok arányával képeztük le. Ez utóbbi alapmutató általánosan azt is bemutatja, hogy egy adott ország fiataljai mennyire tartják vonzó pályának a közgazdasági területet. A pénzügyi oktatási rendszer színvonalának mérése kapcsán felmerült az intézményi rangsorokban (például: a Financial Times European Business School Ranking-je, Financial Times 2017) szereplő intézmények számának használata is, azonban ezt végül elvetettük, mivel véleményünk szerint egy-egy kimagasló intézmény önmagában nem feltétlenül képezi le megfelelő módon a teljes felsőoktatási szektor színvonalát. Talán a bankrendszer humán oldala az, amely összehasonlításunkban a szükségeshez képest a kisebb súlyt kapta, így fontos fejlesztési irány lehet ennek jobb mérése. 
Az árazás látszólag könnyen számszerüsíthető mutatókat ölel fel, de a gyakorlatban nehézséget okoz, hogy a nemzetközi összehasonlíthatóság érdekében ki kell küszöbölni az országok kockázati felára közötti - bankrendszertől független - különbségeket és az eltérő monetáris politikai adottságokat, amelyek egyaránt tovagyűrűzhetnek a kamatokba. Ennek feloldására nem a szintbeli mutatókat, hanem a hitelfelárakat és a hitel-betét különbözetet hasonlítottuk össze az egyes országok között. Elemzésünk során - lakossági és vállalati területen egyaránt - a hitelek abszolút kamatszintje helyett a kamatfelárak 3 havi átlagos értékét alkalmaztuk, így a hitelezés általános kockázata (beleértve az egyes nemzetgazdaságok országkockázati felárát) kimutatásra került a modellben. A vállalati hitelek és betétek árazása emellett lefedi a KKV-k és a nagyvállalati szektor spreadjei közötti különbséget, ugyanis a KKV-szektor hitelezését hasonlóan fontosnak tartjuk, mint a nagyvállalati szegmensét, a bevonó és fenntartható növekedés egyik zálogaként. A két szektor közötti árazási különbség a „hitelkamat spread” mutatóban jelenik meg, amely a KKV-k és a nagyvállalati szektor eltérő kockázati megítélését tükrözi a finanszírozók szemszögéből. Bár a KKV-któl elvárt kamat a magasabb kockázat alapján indokolhatóan valamivel nagyobb, a túlzó különbség kiszorítja a kisvállalatokat a hitelpiacról, ami pedig gátat szab a növekedésünknek. A túlzottan magas tőkeköltség kevés projekt esetén eredményezhet pozitív nettó jelenértéket. Ha a KKV-k mégis belevágnak, kétséges marad a finanszírozás kigazdálkodhatósága, azaz bizonyos kamatküszöb felett hitelezni éppen hogy kontraproduktív a bankok kockázati költségére, valamint a teljes nemzetgazdaság egészére nézve.

A lakossági hitelek és betétek árazásának mérése saját számításon alapul, az EKB adataira építve. Az alpillérbe alapmutatóként beépítettük a lakossági hitel-betét marzs mutatót, továbbá vizsgáltuk a hitelek kamatfelárát, illetve a THM és hitelkamat közötti különbözetet. Előbbi mutató a vállalati „marzs” mutatóhoz hasonlóan kettős tartalommal bír, a kamatfelárak a referenciakamat és a hitelkamat közötti különbözetet mutatják, a THM és a hitelkamat különbözete pedig néhány egyedi költségtényezőből fakad. A lakosság adósságszolgálata arányos a hitelek árazásával. Amennyiben ez az árazás túlzó, az adósságszolgálat egy eleve kifeszített pozícióból indul, exogén sokkhatás okozta stressz esetén komoly társadalmi károkat és bizalomvesztést okozva a pénzügyi rendszerben. Hosszú távon az intézményi bizalom csak versenyzői piac kikényszerítette moderált árazás mellett születhet meg.

A banki árazás megítélését a hitelek és betétek árazásától külön alpillérben szerepeltetjük, ugyanis előbbi pillér kevésbé mérhető és egymással összehasonlítható mutatókon alapul, utóbbi viszont egzakt kamat- és költségszinteket jellemez. A banki árazás megítélése a vállalati szektor érzékelését modellezi, a szolgáltatások díjazásának árszínvonalát méri a felhasználók körében. Az alpillér szerkezetének összeállítása során célunk a vállalati és a bankszektor kapcsolatának feltérképezése volt, amely jelen esetben a vállalatok banki szolgáltatásokhoz való hozzáállását 
mutatja. Az alkalmazott felméréses alapú mutatók a vállalatvezetők véleményét tükrözik, az alkalmazott három alapmutató közül kettő szubjektív, egy pedig objektív értékítéleten alapul. A szubjektív dimenzióban a pénzügyi szolgáltatások megfizethetőségét, illetve a banki kamatok kigazdálkodhatóságát mérjük. $A$ „pénzügyi szolgáltatások költségeinek megfizethetősége" mutató - a WEF felmérése alapján - a vállalatvezetők szubjektív értékítéletét mutatja a banki szolgáltatások árazásáról. A „kamatokat és költségeket túl magasnak érzők aránya” mutatóban a vállalatvezetők a hitelforrások költségeit hasonlítják saját megtérülési mutatóikhoz, így véleményezik a hitelkamatok kigazdálkodhatóságát. $A$,,banki költségek emelkedését érzők aránya" mutató tárgyilagosabban igyekszik mérni, hogy a vállalatvezetők az előző évhez viszonyítva érzékelnek-e árszínvonal-változást a banki termékek piacán. A kérdésfeltevés azonban némi torzítással jár, ugyanis a megkérdezett vezetők csak azokról a bankokról, illetve termékekről képesek véleményt alkotni, amelyekkel kapcsolatban állnak, így az általános árszínvonal-változás csak megfelelő aggregálással lenne mérhető. Sajnálatos, hogy az alpillérben felhasznált adatok minden esetben felmérésen alapulnak. Ennek oka lehet, hogy a költségek nem standardizáltak, sok esetben rejtettek, így konkrét mérésük nehézségekbe ütközik.

Összességében a bankrendszeri versenyképességet keresleti oldalról mérő Vállalati és háztartási finanszírozási index intuitív, a fejlettséggel korreláló eredményeket mutat. A rangsor elején Svédország, az Egyesült Királyság és Finnország végzett, míg felhasználói szempontból a legkevésbé versenyképes bankrendszerrel rangsorunk alapján Bulgária, Románia és Görögország rendelkezik (2. ábra). A lista első felében nyugat-európai és skandináv bankrendszerek állnak, amelyek versenyelőnye legfőképpen a banki infrastruktúra kiépítettségében, valamint a digitalizáltság magas szintjében mérhető. A lista végén helyet foglaló bankrendszerek versenyhátránya jellemzően mindhárom témakörben azonosítható, tehát az alacsonyabb minőségű, korlátozott hozzáférhetőséggel nyújtott szolgáltatások esetükben még viszonylag magas költségszinttel is párosulnak. A sereghajtó gazdaságok bankrendszerei jellemzően alacsony szinten digitalizáltak, ügyfeleik között a szolgáltatások köre kevésbé ismert és kihasznált, illetve a hitelek ára - részben a magasabb országkockázati felárból kifolyólag - relatíve magas szinten helyezkedik el. A KKE-régiós országok mediánja két alpillér esetében előzi meg az EU-s mediánt (banki infrastruktúra és szolgáltatásminőség). 


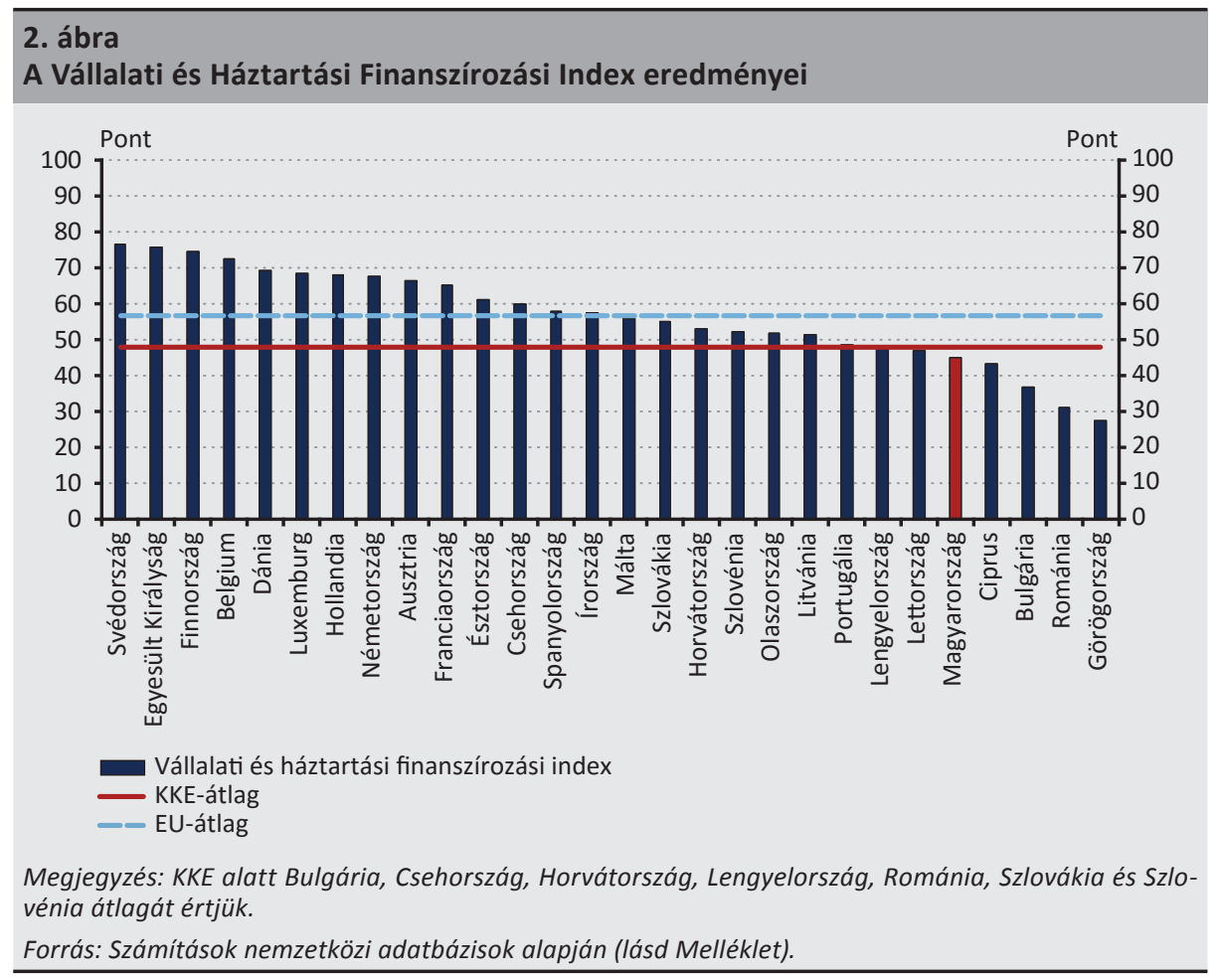

Magyarország a 24. helyen végzett az Európai Uniós országok között 45,0 pontos értékkel. Hazánk eredménye 11,7 ponttal marad el az EU-s tagországok (56,7 pont), és 2,9 ponttal a KKE-régiós országok ${ }^{2}$ (47,9 pont) eredményétől. Hazánk bankrendszeri versenyképességi hátrányának elsődleges forrása a lakossági hitelek magas árazásában, a digitalizáció elmaradásában és a banki termékek alacsony elterjedtségében mutatható ki leginkább, míg a banki szolgáltatások minősége, valamint a banki árazás megítélése és a pénzügyi tudás témakörökben megfelelőnek tekinthető Magyarország versenyképességi pozíciója (lásd 3. ábra). A digitalizációban történő lemaradást egyaránt magyarázzák keresleti és kínálati okok is, hiszen hazánkban még mindig alacsony az online bankolás elterjedtsége (bár a lehetőségei adottak), de a szükséges IT-fejlesztések is sokáig húzódhattak a bankok válság alatti nagyarányú veszteségei miatt. A banki termékek nem kielégítő elterjedtségét szintén indokolhatja egy alacsony kereslet-kínálati egyensúly, továbbá - a kártyás fizetés terjedése ellenére - a készpénz iránti magas kereslet, amit a fizetési infrastruktúra és kultúra továbbfejlesztésével lehet ellensúlyozni.

${ }^{2}$ KKE-régió alatt Bulgária, Csehország, Horvátország, Lengyelország, Románia, Szlovákia és Szlovénia átlagát értjük. 
A finanszírozási index egyes alpilléreiben hazánk kiemelkedően jól teljesített, ami különböző okokra vezethető vissza, de a kapott eredmények összességében konzisztensnek tekinthetőek. A banki szolgáltatások minősége alpillérben a magyar eredmény, a KKE-medián és az uniós medián rendkívül közel helyezkednek el egymáshoz, aminek oka az alkalmazott mutatók alacsony szórása. Az alpillér számítása során néhány kiugró eredményt leszámítva a vizsgált nemzetgazdaságok viszonylag alacsony szórással jelentek meg, a magyar érték pedig a feltüntetett mediánok körül alakult. Mindez a gyakorlatban úgy értelmezhető, hogy a bankszektor szolgáltatásainak minősége az EU területén viszonylag azonos (közepesen magas) szintet képvisel, a versenyképességi különbség sokkal inkább a mennyiségi (pl. árazási) dimenzióban található. A banki árazás megítélése alpillérben Magyarország a KKE-mediánt meghaladva az EU-medián közelében áll. A relatív jó eredmény oka, hogy a vállalatvezetők az elmúlt években a bankok árazásával kapcsolatban pozitív tendenciával szembesültek, így a dinamikára kérdező mutatóban hazánk előkelő helyet foglal el. Az árazás megítéléséről összességében megállapítható, hogy a megkérdezett magyar vállalatvezetők - a gazdaság ösztönzését 2013 óta előtérbe helyező hazai jegybanki politikának, a folyamatosan javuló kockázati megítélésünknek és a kedvező külpiaci környezetnek köszönhetően - a kamatok csökkenését érzékelik, de a szint számukra továbbra is magas, a vállalkozás eredményéhez viszonyítva nehezen kigazdálkodható.

\section{3. ábra \\ MNB Vállalati és Háztartási Finanszírozási Index eredményei alpillérek szerint}

I.A. Banki infrastruktúra

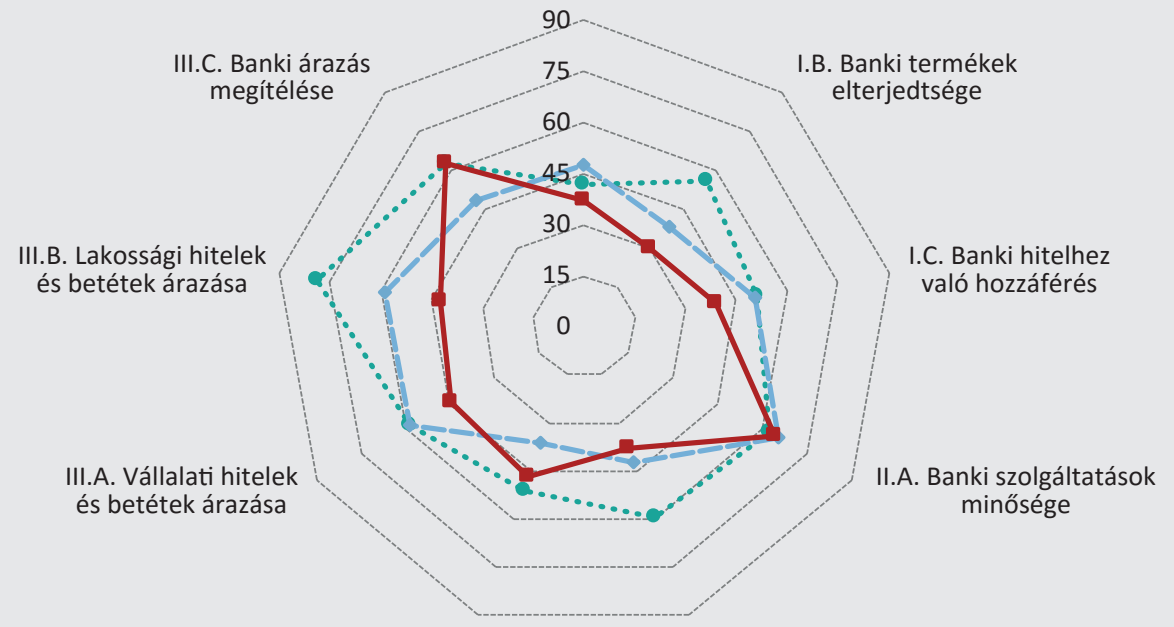

II.C. Pénzügyi tudás

II.B. Banki digitalizáció
••.. EU-medián
$\because$ KKE-medián
- Magyarország

Megjegyzés: A medián értékek alkalmasabbak az átlagnál kifejezni azt, ha valamelyik területen lényeges a lemaradás.

Forrás: Számítások nemzetközi adatbázisok alapján (lásd Melléklet). 


\section{Tökevonzó képesség index (TKI)}

A bankrendszerek versenyképességének másik fontos szempontját az ágazat befektetői oldalának megítélése adja, amit a tőkevonzó képesség indexen keresztül igyekeztünk mérni. Bármilyen szektorról legyen is szó, egy potenciális beruházás sem valósul meg, amennyiben a befektetők számára nem kínál az elvárásoknak megfelelő megtérülést. Ezen logika alapján a bankszektor is csak akkor fejlődhet és járulhat hozzá érdemben a gazdaság növekedéséhez, ha a tulajdonosok számára hosszú távon vonzó befektetést jelent. A makroprudenciális követelmények betartása mellett a befektetők számára egyébként is releváns kérdés egy bankrendszer stabilitása és fenntartható kockázatvállalása, ugyanis az alacsony tőkemegfelelés és nagymértékű nemteljesítő portfólió veszélyezteti a hosszabb távú nyereséges múködést. Kedvező és stabil környezet mellett a tőkevonzás alapvető motorjának a jövedelmezőséget tekintjük, amit különböző skálázott mutatók összesúlyozásával igyekeztünk felmérni.

Számos egyéb tényező befolyásolhatja még a tőkétől elvárt megtérülés teljesülését, így új piacra belépés vagy terjeszkedés során alapvető a piac szerkezete, múködési és adókörnyezete. Ezeket a különbségeket könnyen összemérhető mutatók (pl. a társasági adó mértéke) mellett több kvalitatív tényező (leginkább diszkrét, illetve bináris) számszerűsítésével és összeadásával fejeztük ki. A növekedési lehetőségek jelölik a bankszektor terjeszkedési potenciálját, így szintén információval bírnak az eddig megfigyelt jövedelem fenntarthatóságáról, amihez nagymértékben hozzájárul a költséghatékony múködés is, ezért a szolgáltatások technológiai fejlettségét, valamint a bankok és alkalmazottaik hatékonyságát is megvizsgáltuk.

Információs tartalmuk alapján a finanszírozási kompozit indexhez hasonlóan a tőkevonzó képességhez használt mutatókat is (egymástól nem feltétlenül független, de alacsony korrelációjú) alpillérekbe integráltuk (2. táblázat). Čihák és szerzőtársai (2012) tanulmánya a bankrendszerek és tőkepiacok minőségének felmérésére és összehasonlítására tett nagy ívű kísérletet, új adatbázis építésével. A szerzők négy fő, egymástól jól elhatárolható aspektust határoznak meg: a pénzügyi rendszer méretét (mélységét), a finanszírozás elérhetőségét, a pénzügyi rendszer hatékonyságát, illetve stabilitását. Tanulmányuk megközelítése számunkra is sok tekintetben inspirációt jelentett, klasszifikációjuk saját osztályozásunk alapját is biztosította. A vállalati és háztartási finanszírozási index megfelelően lefedi a finanszírozás elérhetőségét, így a mélység, hatékonyság és stabilitás szempontokat megtartva beemeltük a jövedelmezőség és múködési környezet aspektusait is - ezzel egymástól független dimenziókban megragadva a tőkevonzó képességet. A mi megközelítésünk Čihák és társaival szemben élesen elválasztja a keresleti oldalhoz tartozó versenyképességi lemaradásokat a kínálati oldali problémáktól, amelyeken a bankrendszernek - beleértve a szabályozót is - több lehetősége van változtatni. 


\begin{tabular}{|c|c|}
\hline \multicolumn{2}{|c|}{$\begin{array}{l}\text { 2. táblázat } \\
\text { Az MNB Tőkevonzó Képesség Index felépítése }\end{array}$} \\
\hline & Meghatározó mutatók \\
\hline 1) Stabilitás & $\begin{array}{l}\text { Texas-ratio (a nettó nemteljesítő hitelek állománya a szavatoló } \\
\text { tőke arányában) }\end{array}$ \\
\hline 2) Jövedelmezőség & $\begin{array}{l}\text { Tőkearányos jövedelmezőség, jövedelemarányos költségszint, } \\
\text { értékvesztéssel korrigált eszközarányos díj és kamatbevételek }\end{array}$ \\
\hline 3) Múködési környezet & $\begin{array}{l}\text { Koncentráció, környezeti mutató (jogrend stabilitása, bankadó } \\
\text { és -illeték bevezetése), társasági adó }\end{array}$ \\
\hline 4) Növekedési lehetőségek & $\begin{array}{l}\text { GDP-arányos magánhitelek hosszú távú trendje, GDP-arányos } \\
\text { hazai magánhitelek, háztartások eladósodottsága, bankhitelek } \\
\text { aránya a vállalatok finanszírozásában }\end{array}$ \\
\hline 5) Technológia és hatékonyság & $\begin{array}{l}\text { Online bankolás, díj- és kamatbevételek az alkalmazottak } \\
\text { számának arányában, eszközarányos költségszint }\end{array}$ \\
\hline
\end{tabular}

Tőkevonzó képesség elemzésünket elméleti és gyakorlati elvek egyaránt vezérelték. A stabilitás tekintetében olyan sűrű mutatót választottunk, amely egyszerre tömöríti a rendelkezésre álló szavatoló tőke és az országra jellemző hatékony forrásallokációs döntéseket, azaz valóban azok az ügyfelek jutnak forráshoz, akik képesek és hajlandók visszafizetni a követeléseket - amennyiben pedig nem, úgy a bankrendszer prudens tartalékokat is képez ezekre a veszteségekre. Mindezt a Texas-ratio adja meg nekünk. A jövedelmezőséget is széles körben igyekeztünk értelmezni, vagyis nem pusztán a profitabilitás tényét, hanem annak költségvonzatait is figyelembe vettük mind a múködési, mind a kockázati sorokon. A múködési környezet kapcsán az indexünk nyitott további alapmutatókra, mind a felügyeleti hatóság függetlenségét, hatékonyságát, mind az adatszolgáltatások és szabályozói megfelelések egyszerűségét illetően - ebben az európai országok közötti variabilitás mélyen húzódik. Részleges megoldást nyújt például a vállalati adókulcs, amely nemcsak közvetlen módon csökkenti a bankok jövedelmezőségét, hanem a könnyű összehasonlíthatóság révén az állami redisztribúció fokában lévő szintkülönbséget is kifejezi. A működési környezetben kívántuk megragadni a piaci erő koncentrációját is, azonban e mutatónál a hatás iránya korántsem egyértelmű. A nagyobb koncentráció összekapcsolható az oligopolisztikus piaccal (SCP-paradigma, illetve a „quiet life” hipotézis, Id. Hicks 1935), ami előnytelen helyzetbe hozhatja a kisebb részesedéssel rendelkező résztvevőket, az alacsonyabb koncentráció pedig megkönnyítheti a belépést, mivel kisebb intézetek felvásárlására kevesebb tőkét kell fordítani. Továbbá sok kis résztvevő integrálása egy nagyobb intézetbe jelentős ráfordításokat igényelhet. Amennyiben a piacot több jelentős intézet uralja, a belépés lehetséges relatíve kevés tőkével és további integráció nélkül. Mindemellett a koncentráció és a verseny intenzitása közötti első látásra egyértelmű negatív összefüggés a szakirodalom szerint sem törvényszerü, Id. például Berger (1995), Claessens - Laeven (2004), van Leuvensteijn et al. (2013) eredményeit. Mivel az optimális koncentráció meghatározása ebből kiindulva nem feltétlenül lehetséges, ideális szintként a bankrendszerekben meg- 
figyelt átlagos koncentrációt határoztuk meg, az egyes országok pontszámát pedig ez esetben az átlagtól számított távolság adja meg. A szakirodalomban alkalmazott mutatók közül a Herfindahl-Hirschman-indexet (HHI) választottuk, mivel CR3 és CR5 (legnagyobb bankok piaci részesedése) mutatókkal szemben a kisebb résztvevőkről is hordoz információt. A növekedési lehetőségeket fontosabbnak láttuk megragadni a pénzügyi mélységnél, mivel megítélésünk szerint utóbbi még inkább kereslet vezérelt. A túlfútöttség mellett azonban az aktivitás hiánya is könnyen visszariaszthatja a befektetóket, különösen, ha a hitelek iránti mérsékelt érdeklődés hátráltatja a hitelezést és az intézmény megtérülő múködtetését. Az egyes mutatók optimális értékét (minimum vagy átlag) azzal a céllal határoztuk meg, hogy mindkét hatás kellő mértékben érvényesüljön. A kereslet a technológia esetében is befolyásoló szereppel bír, de itt a bankrendszer jobban orientálhat. Mivel a piacon meglévő bankok tőkevonzó képességével definiáltuk a versenyképesség ezen oldalát, a hatékonyságot egyértelműen pozitív tényezőként értelmeztük, hiszen a hatékonytalan intézmények felvásárlása további beruházásokat, illetve szervezeti átrendeződést igényel a költségracionalizálásból adódó hasznokon túl.

A potenciális szempontok és mutatók (részletesen lásd a 2. mellékletben) mérlegelése után a táblázatban lévő öt alpillért határoztuk meg 14 alapmutató alkalmazásával, amelyeket 0-tól 100-ig terjedő skálán értékelünk. Az alpillérek egyenlő súllyal lépnek be a tókevonzó képességet kifejező kompozit indexbe a módszertani fejezetben tárgyaltak szerint. Az összehasonlíthatóság érdekében az alpillérekben megjelenő mutatókat is egységes skálán fejeztük ki. A multikollinearitás elkerülésének érdekében korrelációs analízis segítségével zártuk ki a többletinformációval nem rendelkező mutatókat, ezzel sikerült elérnünk, hogy az alpillérek között nincs közepesen erős korreláció sem - függetlennek tekinthetők. Megjegyezzük, hogy elemzésünkben nem teszünk különbséget külföldi tulajdonú és hazai tulajdonú bankok között az egyes országokban, és ezzel összefüggésben mindvégig konszolidált adatokkal dolgozunk.

A tőkevonzó képesség index tanúsága szerint (lásd 4. ábra) a sereghajtó országok azok, amelyeknél a legszúkebb keresztmetszetet a stabilitási szempontok adják: Görögország, Ciprus, Olaszország és Portugália. Az élen a balti és skandináv bankrendszerek állnak (valamennyi balti ország bekerült az első tíz közé), amit kiegyensúlyozott, prudens, költséghatékony és kellően digitalizált múködésük magyarázhat. Az említett nemzetgazdaságok jóval kevésbé folytattak túlfütött, „ragadozó” típusú hitelezést a válság előtt, így a válságkezelés is alacsonyabb mértékű növekedési áldozatokkal valósulhatott meg. Tőkevonzó képesség tekintetében az első tízbe került még Spanyolország és az Egyesült Királyság is, amelyek válság előtti meghatározó, központi szerepe Latin-Amerika, illetve Európa bankolásában (cross-border financing) részben magyarázza előnyös pozíciójukat. A felsorolt országok sokat tettek azért is, hogy kevésbé hatékonyan múködő bankjaikat digitális innovációkon keresztül megújítsák, az átállás pozitív hatásai pedig napjainkra mérhetővé váltak. 


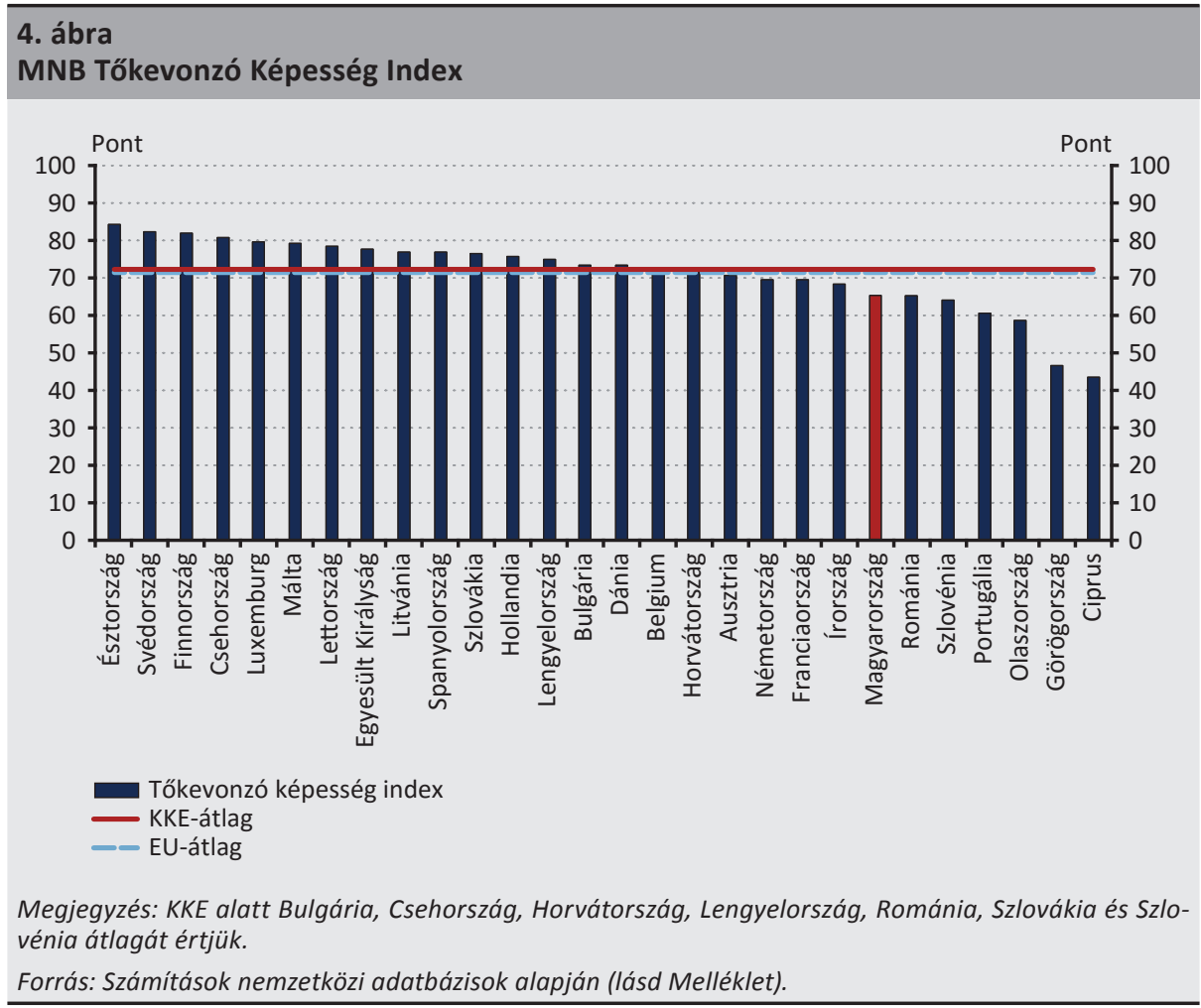

Magyarország a tőkevonzó képesség index rangsorolásában - hasonlóan a vállalati és háztartási finanszírozási indexhez - az utolsó harmadban található, a KKE-átlag alatt, csak Romániát és Szlovéniát megelőzve. A tőkevonzó képesség index öt alpillérjét elemezve (lásd 5. ábra) elmondható, hogy stabilitás tekintetében a KKE-átlagot is meghaladjuk, amiben jelentős szerepe volt egyrészt az anyabanki tőkejuttatásoknak a válság után, másrészt a közelmúlt stabilizáló jegybanki lépéseinek, illetve néhány nagyobb szereplő eredményes múködésének. A jövedelmezőségi pillérben Magyarország a rangsor végén helyezkedik el, mivel míg az eszközarányos nettó kamat- és díjjövedelem tekintetében az első helyet foglaltuk el, addig a magas kockázati költség és a jövedelemarányos költségszint mutató jelentősen rontja a végleges pontszámot. A múködési és adókörnyezetet tekintve a rangsor első felében helyezkedünk el a vállalati adókulcsnak és a piaci koncentrációnak köszönhetően, a környezeti index azonban a középmezőny felé húzza a magyar bankrendszer helyezését. A növekedési dimenzió kedvező potenciált mutat hazánk esetében, ami az alacsony hiteltrendnek és a háztartási hitelezésben rejlő lehetőségeknek köszönhető. Végezetül technológia és hatékonyság tekintetében Magyarországnál csak Románia és Bulgária ér el rosszabb helyezést, amihez valamennyi figyelembe vett mutató hozzájárult, tehát lemaradásunk elsősorban itt azonosítható. 


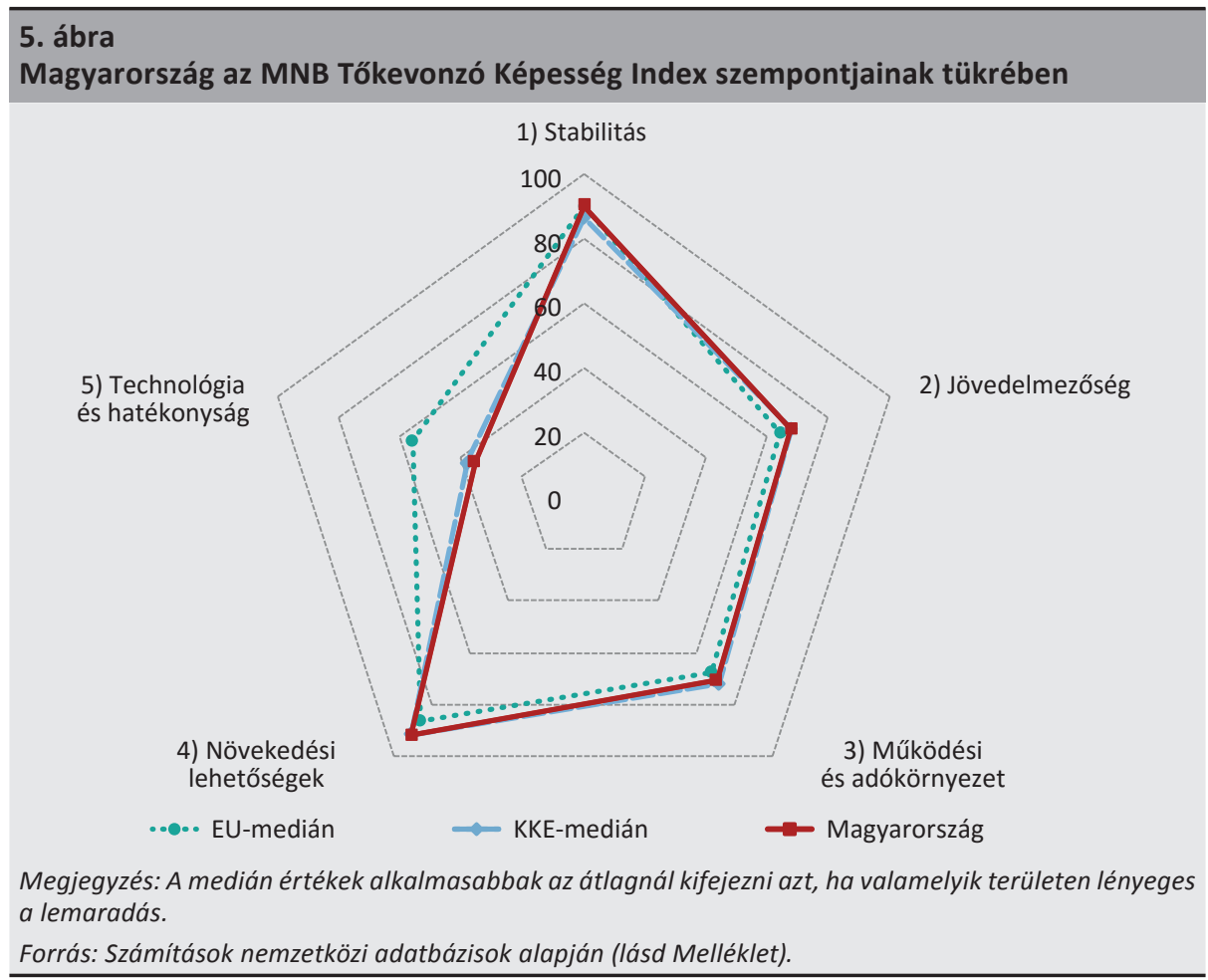

\section{MNB bankrendszeri versenyképességi index (BVI)}

A felhasználói és a befektetői oldali versenyképesség közötti statikus ellentét az idővel oldódik, és ezek hosszabb távon egymást erősítő tényezőkké válhatnak. Nézőpontunk szerint a versenyképes bankrendszer magas színvonalon, széles körben biztosítja a hozzáférést, árazása alkalmazkodik a befektetői hozamelvárásokhoz, de kigazdálkodható a felhasználói oldal számára is. Ezzel szemben, ha egy adott országban alacsony a tőkevonzó képesség és így nem tud kiépülni megfelelő banki infrastruktúra, akkor gyengébb lesz a pénzügyi mélyülés, és a mérethatékonyság hiánya miatt csökken a pénzügyi közvetítés hatékonysága. A drágább, alacsonyabb minőségű kiszolgálás és gyengülő elérhetőség egyre kevésbé hatékony működéshez vezet, ami pedig csökkenő tőkearányos megtérülést és még alacsonyabb tőkevonzó képességet eredményez. A banki kínálatnak ezért hosszú távon a kereslet szempontjaihoz kell alkalmazkodnia, figyelembe véve nemcsak a múlt tanulságait, de a jövőben egyre gyorsuló technológiai változásokat is, amelyek elérik lassan a pénzügyi közvetítő rendszert is. 
Az előző fejezetekben két eltérő nézőpont alapján próbáltuk felmérni a bankrendszer versenyképességét, egyrészt a felhasználók, másrészt a banktőke oldaláról. Önmagában azonban mindkét megközelítés kevés és féloldalas: egy valóban versenyképes bankrendszer esetében mindkettő egyszerre teljesül, lehetőség szerint kibékítve a két oldal között fennálló ellentéteket. A teljes „MNB bankrendszeri versenyképességi indexben" tehát mindkét részindexet figyelembe vettük annak érdekében, hogy mérhetővé váljon, mely országokban sikerül a leginkább összeegyeztetni a felhasználói és befektetői igényeket a bankrendszer múködésében. ${ }^{3}$

Felmérésünk szerint - mindkét vizsgált oldalt figyelembe véve - az északi országokban és az EU magjának számító tagállamok egy részében a legerősebb a bankrendszer versenyképessége. Németország bankrendszere a küszködő nagybankok (Deutsche Bank, Commerzbank) ellenére, feltehetően a kevésbé prociklikusan működő szövetkezeti modellnek (Sparkassen) köszönhetően, inkább versenyképesnek tekinthető. A kelet-közép-európai tagállamok nagy része - köztük Magyarország is - összességében átlag alatti eredményt ért el. A leggyengébb versenyképességet a dél-kelet-európai és mediterrán országok: Portugália, Olaszország, valamint Görögország bankrendszere mutatja.

Magyarország egy csoportba kerül Lettországgal, Írországgal és Lengyelországgal, valamint két észak-nyugat-balkáni (Szlovénia, Horvátország) állammal. Keresleti és kínálati oldalról is azonosíthatóak a hazai előrelépési lehetőségek, de kiváltképp összeér a két aspektus a digitalizáció és a múködési hatékonyság fejlesztésében. Ezenfelül egy versenyzőbbé váló bankrendszeren keresztül a hitelfelárak és -költségek csökkenése mentén elinduló hatékonyságjavulás jelent még olyan lehetőséget, amely hosszabb távon is biztosíthatja a hazai bankrendszer gazdasági növekedést támogató és társadalmilag elfogadott allokáló szerepét.

\footnotetext{
${ }^{3} \mathrm{~A}$ két részindexet több módon is összesúlyoztuk, de az eredmények robusztusak voltak. Itt a számtani átlag szerinti eredményt mutatjuk be.
} 


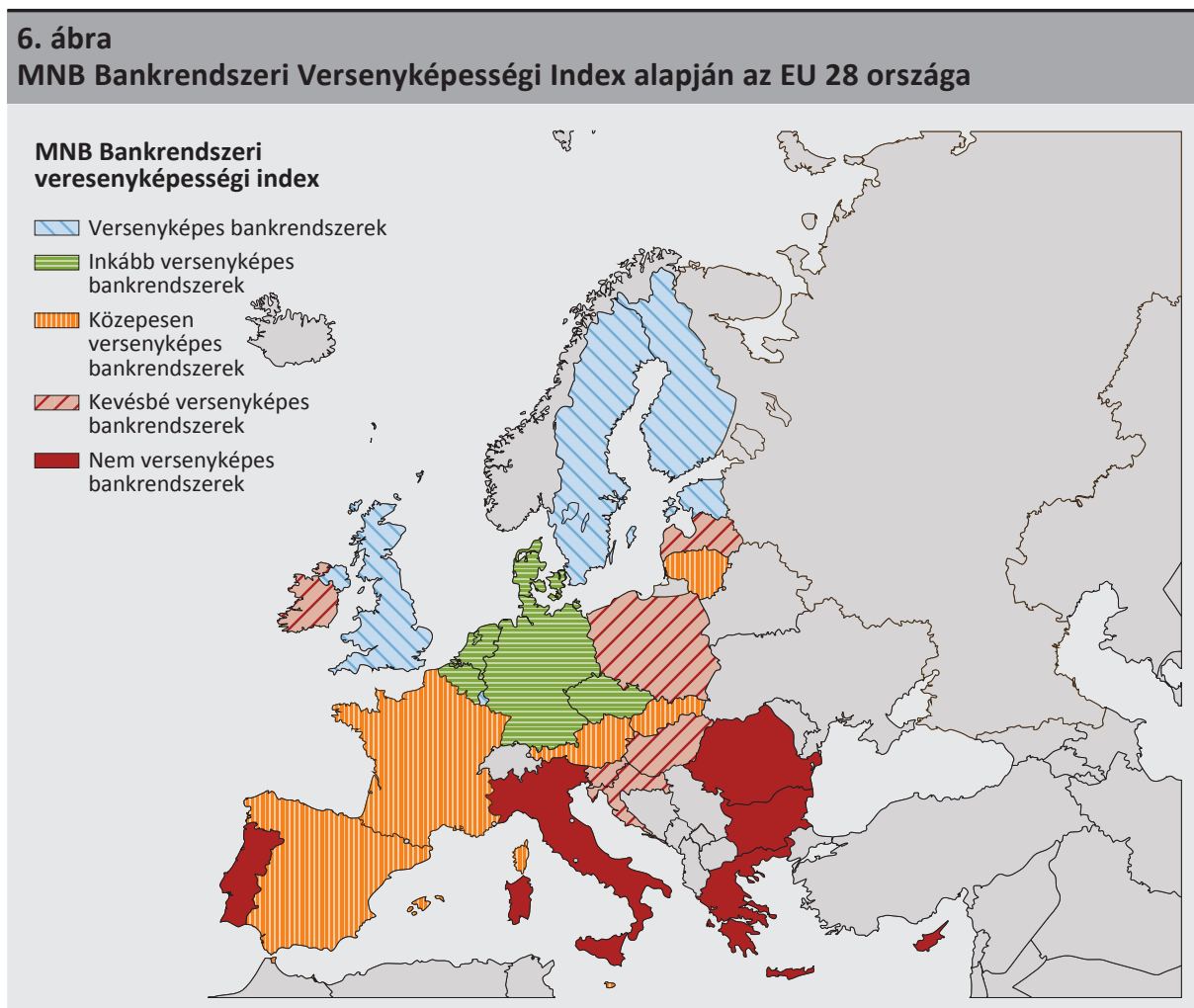

Megjegyzés: Az MNB Vállalati és háztartási finanszírozási és az MNB Tőkevonzó képességi indexeinek átlagolásával számolt rangsor alapján.

Forrás: MNB.

Érdemes megvizsgálni, hogy az általunk kapott eredmények miként viszonyulnak a hasonló témában elérhető nemzetközi vizsgálatokhoz. Amint a bevezetőben jeleztük, ilyen átfogó összehasonlítást nem találhattunk a bankrendszer területén, de a versenyképességi rangsorok parciálisan kitérnek a pénzügyi közvetítés néhány aspektusának vizsgálatára. Az összehasonlításhoz a „Doing Business” (World Bank 2017), a „Global Competitiveness Report” (Schwab 2017) és a „World Competitiveness Yearbook” (IMD 2017) felméréseket használtuk, amelyek egyenként a bankrendszer 4-9 mutatóját tartalmazzák. Az egyes rangsorok pénzügyi közvetítéssel foglalkozó kérdéseiben elért átlagos pontszámok és helyezések közötti összefüggések meglehetősen hasonló mintázatot mutatnak (3. táblázat). A WEF- és az IMD-rangsorok eredményei erősen korrelálnak a saját eredményeinkkel (minden esetben $r>0,79$ ), miközben a Doing Business rangsorának esetében ennél gyengébb összefüggést tapasztaltunk (a pontszámok esetében $r=0,48$, míg a helyezések tekintetében $r=0,51$ ). Fontos ugyanakkor megemlíteni, hogy a Doing Business a másik két versenyképességi rangsorral sem korrelál nagyobb mértékben, ugyanis ez kifejezetten a KKV-k üzleti környezetére koncentrál, miközben a többi rangsor ennél némileg tágabb szempontrendszer alapján vizsgálja a bankrendszer múködését és eredményességét. 


\begin{tabular}{|c|c|c|c|}
\hline \multicolumn{4}{|c|}{$\begin{array}{l}\text { 3. táblázat } \\
\text { Az MNB Bankrendszeri Versenyképességi Index keresztellenőrzése }\end{array}$} \\
\hline Korrelációs együtthatók & $\begin{array}{c}\text { World Bank - Doing } \\
\text { Business }\end{array}$ & $\begin{array}{l}\text { World Economic Forum } \\
\quad-\text { Global } \\
\text { Competitiveness Report }\end{array}$ & $\begin{array}{l}\text { IMD - World } \\
\text { Competitiveness } \\
\text { Yearbook }\end{array}$ \\
\hline MNB BVI & 0,47 & 0,89 & 0,86 \\
\hline MNB VHFI & 0,47 & 0,79 & 0,87 \\
\hline MNB TKI & 0,30 & 0,70 & 0,48 \\
\hline
\end{tabular}

\section{6. Összegzés}

Elemzésünk célja a bankrendszeri versenyképesség értelmezése, illetve elsősorban annak számszerű nemzetközi összehasonlítása volt az Európai Unió tagállamaiban. Ilyen mértékben átfogó és mélységében is alapos nemzetközi kutatást nem találtunk, ezért mind a mutatók kiválasztása, mind csoportosítása során új dilemmákba ütköztünk. Az alapvető ellentmondások feloldása érdekében a kutatás két különböző perspektívából - felhasználói, illetve befektetői szemszögből - vizsgálta a témakört, amelynek eredményeként egy finanszírozási és egy tőkevonzó képességi, majd egy ezekből összevont versenyképességi indexet alkottunk meg. Hosszú távon a két preferenciarendszer egyidejű teljesülése a legkedvezőbb, így a két index kombinációját mutatja az MNB bankrendszeri versenyképességi index. Mivel elsősorban strukturális jellegű mutatókra fókuszáltunk, hogy ne a gazdaság ciklikus pozícióját tükrözze az összehasonlítás, az elemzést kétéves periódusokban látjuk érdemesnek frissíteni.

Reményeink szerint a feltárt eredmények nemcsak rangsorolási céllal használhatóak, hanem alapot szolgáltathatnak a jövőben fejlesztendő területek, neuralgikus pontok meghatározására. A kutatás továbbvitele két dimenzióban történhet: egyrészt az index fejlesztésével, a mutatószámrendszer bővítésével és rendszeres frissítésével. Ebből kifolyólag egy széleskörű és konszolidált adatszerzés, illetve átfogó nemzetközi közvéleménykutatások bevezetése is célszerű lenne a felvázolt alpillérek dimenzióiban. Másrészt érdemes mélyebben megvizsgálni a bankrendszer és a nemzetgazdasági versenyképesség kapcsolatát, ezen belül például azon csatornákat részletesebben, amelyeken keresztül a bankrendszer hozzájárulhat egy adott ország versenyképességéhez. Ez utóbbi kutatáshoz reményeink szerint felhasználhatóak az itt bemutatott első eredmények is. 


\section{Felhasznált irodalom}

Banai Ádám - Horváth Gábor - Vonnák Balázs: A pénzügyi közvetítés szerepe a növekedésben. Versenyképesség és növekedés. Magyar Nemzeti Bank, 2016: 186-211.

Berger, A. N. (1995) The Profit-Structure Relationship in Banking: Tests of Market-Power and Efficient-Structure Hypotheses. Journal of Money, Credit, and Banking, 27(2), May: 404-431. https://doi.org/10.2307/2077876.

Claessens, S. (2009): Competition in the Financial Sector: Overview of Competition Policies. World Bank Research Observer, 24(1): 83-118. https://doi.org/10.1093/wbro/lkp004.

Claessens, S. - Laeven, L. (2004): What Drives Bank Competition? Some International Evidence. Journal of Money, Credit and Banking, 36 (3), June: 563-583. https://doi. org/10.1353/mcb.2004.0044.

Čihák, M. - Demirgüc-Kunt, A. - Feyen, E. - Levine, R. (2012): Benchmarking Financial Systems around the World. World Bank, Policy Research Working Paper 6175, August.

Financial Times (2017): European Business School Rankings 2016. http://rankings.ft.com/ businessschoolrankings/european-business-school-rankings-2016. Letöltés ideje: 2017. augusztus 1.

Gerschenkron, A. (1962): Economic backwardness in historical perspective, a book of essays. Cambridge, Massachusetts: Belknap Press of Harvard University Press.

Hatzichronoglou, T. (1996): Globalisation and Competitiveness: Relevant indicators. OECD STI Working Papers 1996/5, Paris.

Hicks, J. (1935): Annual Survey of Economic Theory: The Theory of Monopoly. Econometrica, 3(1), January: 1-20. https://doi.org/10.2307/1907343.

IMD (2017): World Competitiveness Yearbook 2017. https://worldcompetitiveness.imd.org/. Letöltés ideje: 2017. augusztus 1.

Klaus Schwab, World Economic Forum (2017): The Global Competitiveness Report 20162017. https://www.weforum.org/reports/the-global-competitiveness-report-2016-2017-1. Letöltés ideje: 2017. augusztus 1.

MNB (2014): Átalakulóban a magyar bankrendszer: Vitaindító a magyar bankrendszerre vonatkozó konszenzusos jövőkép kialakításához. MNB-tanulmányok különkiadás.

Nafzinger, E. W. (2006): Economic development. Cambridge University Press, New York.

Porter, M. E. (1998): The Competitive Advantage of Nations. The Free Press, New York. https://doi.org/10.1007/978-1-349-14865-3. 
van Leuvensteijn, M. - Sorensen, C. K. - Bikker, J. A. - Van Rixtel, A. A. (2013): Impact of bank competition on the interest rate pass-through in the euro area. European Central Bank, Working Paper Series, March, No. 885. https://doi.org/10.1080/00036846.2011.617697.

World Bank (2017): Doing Business - 2017. http://www.doingbusiness.org/. Letöltés ideje: 2017. augusztus 1. 


\section{Melléklet}

\section{1. melléklet: Vállalati és háztartási finanszírozási index alapmutatói}

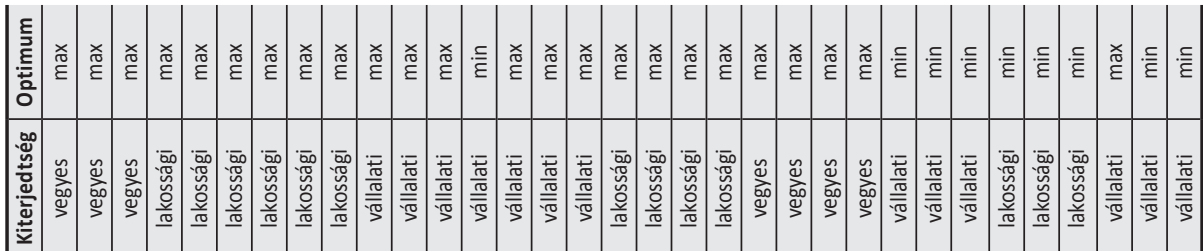
w

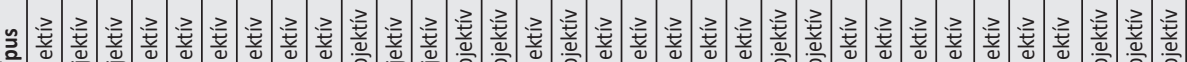

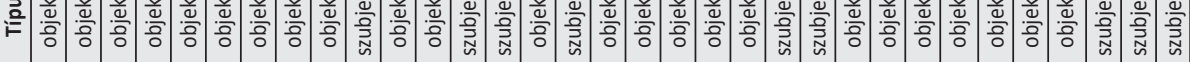

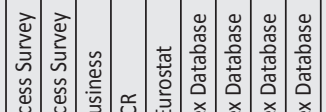

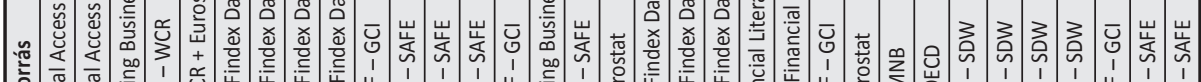

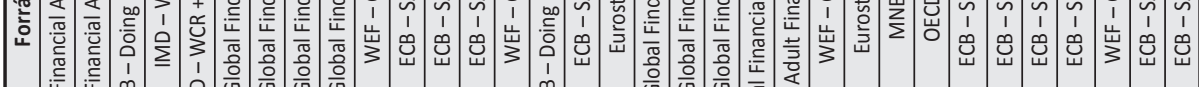

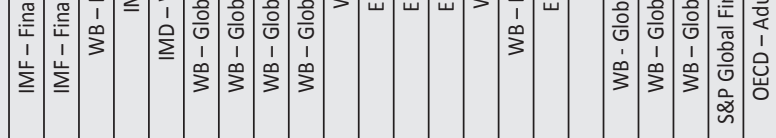

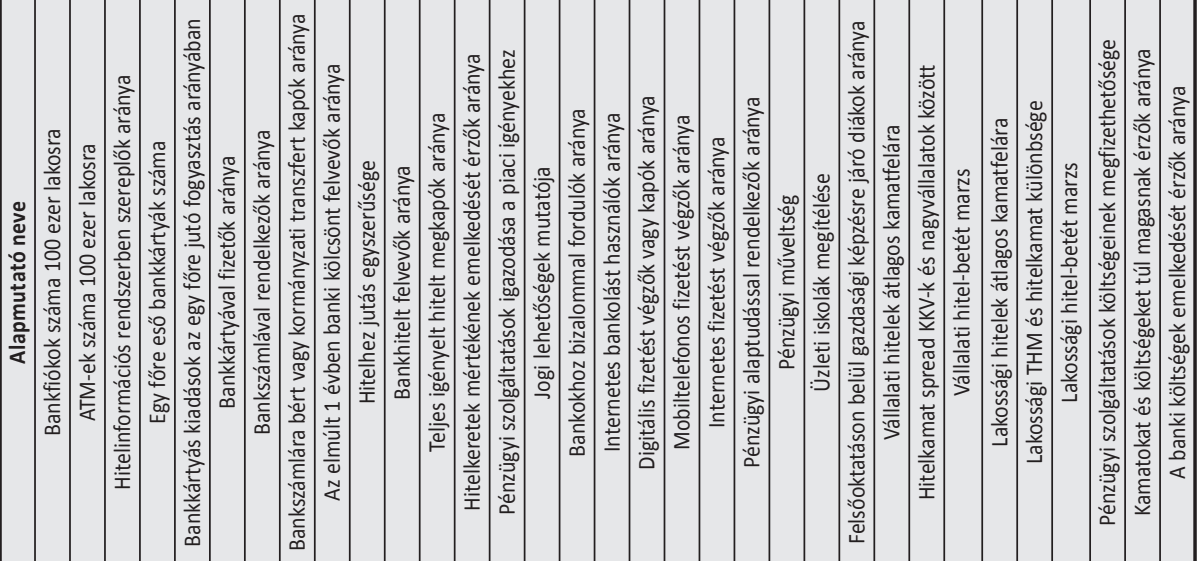

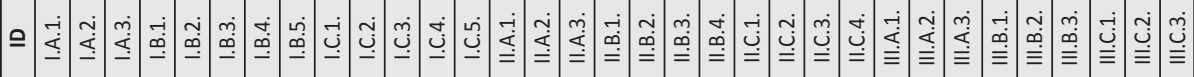

\begin{tabular}{|c|c|c|c|c|c|c|c|c|c|}
\hline 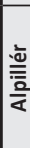 & 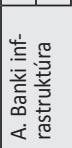 & 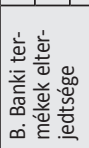 & 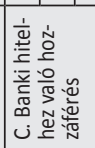 & 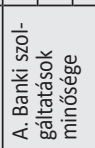 & 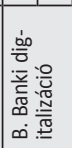 & 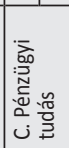 & 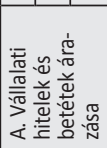 & 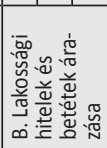 & 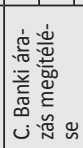 \\
\hline & 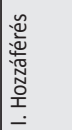 & & & 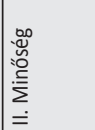 & & & $\begin{array}{l}\text { 胥 } \\
\text { 芠 } \\
\\
\end{array}$ & & \\
\hline
\end{tabular}




\section{2. melléklet: Tőkevonzó képesség index alapmutatói}

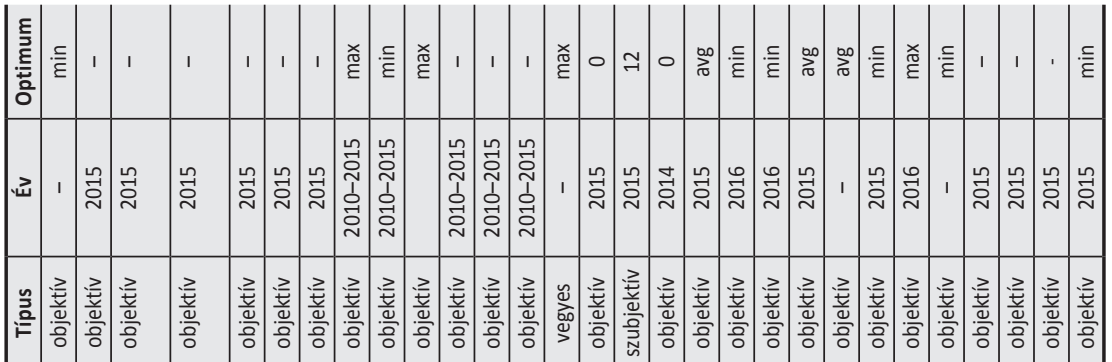

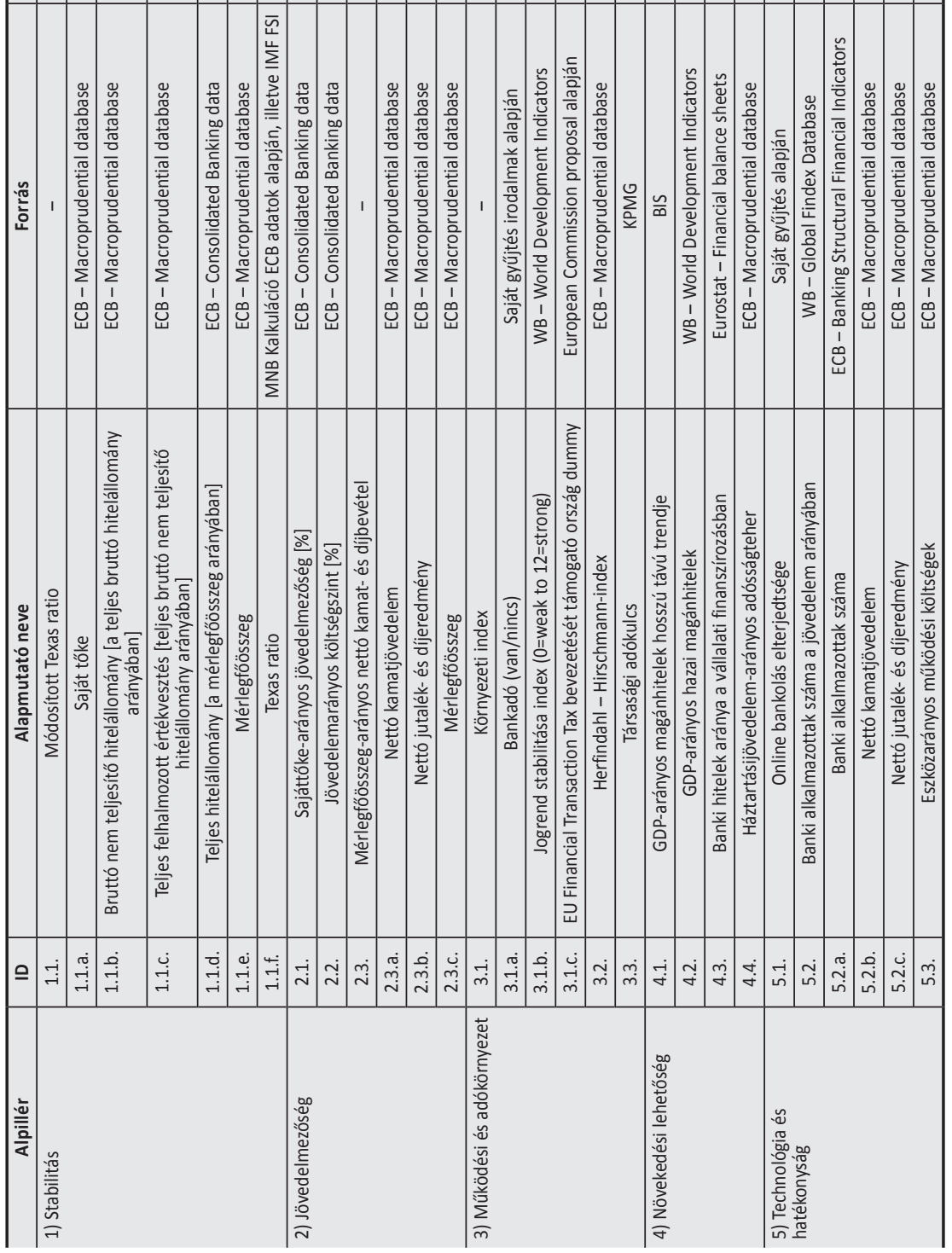

